\title{
Defense manifestations of enzymatic and non-enzymatic antioxidants in Ricinus communis L. exposed to lead in hydroponics
}

\author{
Boda Ravi Kiran ${ }^{1 \star}$ and M.N.V. Prasad ${ }^{1 *}$
}

\begin{abstract}
Lead $(\mathrm{Pb})$ is a major inorganic pollutant with no biological significance and has been a global concern. Phytotoxicity of lead induces toxic effects by generating reactive oxygen species (ROS), which inhibits most of the cellular processes in plants. Hydroponic experiments were performed with Ricinus communis to investigate the toxicity and antioxidant responses by exposing to different concentrations of lead $(0,200$ and $400 \mu \mathrm{M})$ for 10 days. Pb stress caused a significant increase in electrolyte leakage, non-enzymatic antioxidants (phenols and flavonoids) and a decrease in the elemental profile of the plant. Histochemical visualization clearly indicates the significant increase of $\mathrm{H}_{2} \mathrm{O}_{2}$ production in dose-dependent manner under $\mathrm{Pb}$ stress. Likewise, an increase in catalase, guaiacol peroxidase and superoxide dismutase activity was also evident. Ascorbate peroxidase and MDAR, on the other hand, responded biphasically to $\mathrm{Pb}$ treatments showing a decrease in concentration. The decline in redox ratio GSH/GSSG was imposed by the indirect oxidative stress of $\mathrm{Pb}$. Hence these findings showed the ameliorative potential of $R$. communis to sustain $\mathrm{Pb}$ toxicity under oxidative stress.
\end{abstract}

Keywords: Antioxidant enzymes, oxidative stress, $\mathrm{Pb}$ toxicity, reactive oxygen species (ROS), Ricinus communis.

'Department of Plant Sciences, School of Life Sciences, University of Hyderabad, Hyderabad, Telangana 500 046, India

${ }^{\ddagger}$ Currently: Emeritus Professor, School of Life Sciences, University of Hyderabad, Hyderabad, Telangana 500 046, India

*Corresponding author: B. R. Kiran E-mail: ravikiranboda@uohyd.ac.in

DOI: 10.2478/ebtj-2019-0014
(C) 2019 Authors. This work was licensed under the Creative Commons AttributionNonCommercial-NoDerivs 4.0 License.

\section{Introduction}

Environmental pollution by heavy metals poses a threat to all forms of life. Heavy metal accumulation causes deleterious effects to plants as well as human beings. According to the Agency for Toxic Substance and Disease Registry (ATSDR), lead is ranking as top 10 toxic global pollutants which occupy $2^{\text {nd }}, 4^{\text {th }}, 7^{\text {th }}$ and $8^{\text {th }}$ position out of 10 . Despite its antiquity and beneficial use by humanity, it is renowned as a chemical of greater concern in the European REACH regulations (EC1907/2006; Registration, Evaluation, Authorization, and Restriction of Chemicals). Sources of lead pollution to the environment are mainly from metallurgy (smelting of ores, mining, and combustion of coal), energy production (gasoline, batteries, paints, armory, and microelectronics), fertilizers and pesticides $(1,2,3)$.

Lead is a non-essential element, and its toxicity in plants brings adverse effects that disturb the normal functioning of the plants from cell to organ level. This metal impairs stunting growth, transpiration, chlorophyll production, a lamellar organization in the chloroplast, inhibit photosynthesis and cell division $(4,5,6,7)$. Pb absorbed onto the roots and bound to carboxyl groups of mucilage uronic acid, or directly to the polysaccharide of the rhizodermis cell surface (8). $\mathrm{Pb}$ phytotoxicity causes reduction of molecular oxygen and produces intermediate products such as hydrogen peroxide $\left(\mathrm{H}_{2} \mathrm{O}_{2}\right)$ and superoxide anion $\left(\mathrm{O}_{2}^{-}\right)$, singlet oxygen $\left({ }^{1} \mathrm{O}_{2}^{-}\right)$and hydroxyl radical $(-\mathrm{OH})$. These active molecules are involved in free radical chain reaction of membrane lipids causing oxidative stress and DNA damage by altering molecular activities of cell $(9,10,11,12)$. Lead activates certain enzymes by modulating gene expression or by restricting the activity of enzyme 
inhibitors, but its relationship has not been yet clearly established (3). Plants employ inherent defense strategies for metal detoxification whenever confronted with stressful condition. It includes restriction of metal uptake, metal ion trafficking, metal sequestration within the root, biosynthesis of osmolytes and activation of antioxidant enzymes. In order to quench ROS and to cope up, plants also developed defense mechanism by activation of enzymatic and non-enzymatic antioxidant such as catalase (CAT), ascorbate peroxidase (APX), guaiacol peroxidases (GPX), superoxide dismutases (SODs) and glutathione (GSH) $(10,13,14,15)$. SOD is considered as a first line defense against oxidative stress by converting $\mathrm{O}_{2}$ - into $\mathrm{H}_{2} \mathrm{O}_{2}$ and subsequently detoxified by APX in the ascorbate-glutathione cycle or by GPX and CAT in the cytoplasm. A non-enzymatic antioxidative system like phenols, flavonoids, glutathione, etc., plays a significant role in scavenging ROS and protecting the membrane damage caused by free radicals. The oxidized form of glutathione (GSSG) is converted to reduced glutathione (GSH) by glutathione reductase (GR) $(16,17,18)$. Lead uptake, accumulation, and tolerance have been investigated in number of terrestrial plants such as Sophora japonica \& Platycladus orientalis (19); Pisum sativum (20); Coronopus didymus (14); Peganum harmala (11); Jatropha curcas (21) and Oryza sativa (6); Helianthus annus (13); Zygophyllum fabago (12).

Castor bean (Ricinus communis L.) is a terrestrial suckering perennial crop grown widely in India, China, Brazil and other parts of the world. It is a multipurpose plant cultivated for phytostabilization and bioenergy production (22). It has been reported that castor bean can grow luxuriantly in contaminated soils due to its tolerance to heavy metals (23). Compartmentalization of $\mathrm{Pb}^{2+}$ ions within the roots and reduced translocation towards shoots is a well-adaptive response of the plants against $\mathrm{Pb}$-toxic conditions (24). Previous studies reported that castor bean have been used for risk assessment studies of different toxic metals such as $\mathrm{Cd}(25,26,27) ; \mathrm{Cu}(28) ; \mathrm{Ni}(29)$ and As (30). One method to evaluate the potential for a species to tolerate high metal concentration is through hydroponic culture. It involves the growing of plants with minimal or no soil to support root systems. Even though they were not extrapolated to soil, nevertheless they are used as a means to assess the capacity to tolerate relatively high metal concentrations by maintaining fast growth rate and high biomass production. Hydroponics experiments produce adventitious roots that are convenient to harvest and have advantage over soil since the roots are directly exposed to water and plant metal interactions are direct without any interference. Thus, roots exhibit true $\mathrm{Pb}$ toxicity. Our earlier study investigated in $R$. communis has demonstrated the $\mathrm{Pb}$-induced toxicity markly increase malondialdehyde (MDA), proline, anthocyanin, cell death and a decrease in photosynthetic pigments $(31,32)$. Therefore, the idea of the present study aims to understand $\mathrm{Pb}$ tolerance in terms of chlorophyll fluorescence, antioxidant metabolism, ROS production and elemental mapping by SEM-EDX to provide insights on $\mathrm{Pb}$-toxicity defence strategies in roots under hydroponic condition.

\section{Material and Methods}

\section{Plant description and treatment in hydroponics}

Seeds of castor bean variety DCS-108 was procured from IIOR (Indian Institute of Oil Research), Hyderabad. Seedlings of uniform size were placed in a conical flask containing $100 \mathrm{~mL}$ of modified Hoagland's media in plant growth chamber for $16 / 8 \mathrm{~h}$ day/night and at $28 \pm 2^{\circ} \mathrm{C}(33)$. The nutrient media was replaced every 3-4 days to provide a fresh dose of nutrient elements. After four weeks of acclimatization, saplings of uniform height were selected and treated separately with $\mathrm{Pb}\left(\mathrm{NO}_{3}\right)_{2}$ at different concentrations $(200 \mu \mathrm{M}$ and $400 \mu \mathrm{M})$ maintained under above conditions. The control plants were without metal treatment. Roots excised after ten days of treatment processed for analysis at various endpoints described as follows.

\section{Chlorophyll fluorescence}

Chlorophyll a (Chl a) fluorescence variables were measured on same leaves which were used previously for leaf gas exchange measurements by using MINI- version of imaging PAM (Heinz Walz GmbH, Effeltrich, Germany). For dark adapted parameters, leaves were adapted in dark for $20 \mathrm{~min}$ to evaluate the maximal photochemical efficiency $\left(\mathrm{F}_{\mathrm{m}}-\mathrm{F}_{0}\right) / \mathrm{F}_{\mathrm{m}}=\mathrm{F}_{\mathrm{v}} / \mathrm{F}_{\mathrm{m}}$ of photosystem-II. While effective quantum yield $\left(\mathrm{F}_{\mathrm{m}}{ }^{\prime}-\mathrm{F}\right) / \mathrm{F}_{\mathrm{m}}{ }^{\prime}=$ $\left.\Delta \mathrm{F} / \mathrm{F}_{\mathrm{m}}{ }^{\prime}\right)$ under natural light conditions. Measurements were taken on adaxial surface of leaves and high light flash of 4000 $\mu \mathrm{mol} \mathrm{m} \mathrm{m}^{-2} \mathrm{~s}^{-1}$ was used for $0.8 \mathrm{~s}$ duration to measure the saturated fluorescence values. Photochemical $\left(\mathrm{F}_{\mathrm{m}}{ }^{\prime}-\mathrm{F}_{\mathrm{s}}\right) /\left(\mathrm{F}_{\mathrm{m}}{ }^{\prime}-\mathrm{F}_{0}{ }^{\prime}\right)=\mathrm{qP}$, and non-photochemical $\left(\mathrm{F}_{\mathrm{m}}-\mathrm{F}_{\mathrm{m}}{ }^{\prime}\right) / \mathrm{F}_{\mathrm{m}}{ }^{\prime}$ fluorescence quenching were also calculated.

\section{Estimation of total phenols, flavonoids and electrolyte leakage (EL)}

The total phenolic content (TPC) was estimated by the folic-ciocalteu spectrophotometric method briefly. $0.1 \mathrm{~mL}$ of extract $(10 \mathrm{ml}$ from $1 \mathrm{~g}$ dry leaf tissue) was mixed with $0.5 \mathrm{~mL}$ of folic-ciocalteu reagent and mixture was shaken. After 5 min $1 \mathrm{~mL}$ of $10 \% \mathrm{Na}_{2} \mathrm{CO}_{3}$ was added and incubated at room temperature for 1 hour. The TPC was measured at $760 \mathrm{~nm}$ by plotting the gallic acid calibration curve (34). Total flavonoids were measured by the aluminum chloride colorimetric assay. $0.1 \mathrm{~mL}$ of extract was mixed with $0.3 \mathrm{~mL}$ each of $5 \% \mathrm{NaNO}_{2}$ and $10 \% \mathrm{AlCl}_{3}$ followed by $2 \mathrm{~mL}$ of $1 \mathrm{M} \mathrm{NaOH}$ and absorbance was measured at $510 \mathrm{~nm}$. The total flavonoids were assessed by plotting catechol as standard (35). For electrolyte leakage (EL), fresh leaf samples $(0.3 \mathrm{~g})$ were washed with distilled water and placed in closed vials $(10 \mathrm{ml}$, deionized) and incubated at 25 ${ }^{\circ} \mathrm{C}$ for 6 hours and electrical conductivity (EC1) recorded with an Electrical Conductivity (EC) meter. Then samples were incubated at $90{ }^{\circ} \mathrm{C}$ for 2 hours and cool down to $25^{\circ} \mathrm{C}$ to record other EC (EC2). The EL of the leaves samples were calculated as: $(\mathrm{EL}(\%)=\mathrm{EC} 1 / \mathrm{EC} 2 \times 100)(36)$.

\section{Structural and elemental mapping}

Structural analyses were done by field emission scanning electron microscope (FESEM, Philips XL-30) for root transverse 
section (TS) of castor treated with 0,200 and $400 \mu \mathrm{M} \mathrm{Pb}\left(\mathrm{NO}_{3}\right)_{2}$ concentration. Elemental mapping was done with energy-dispersive X-ray spectroscopy (EDS, Oxford instruments) coupled with field emission scanning electron microscope (FESEM). Samples for FE-SEM/EDS were prepared by primary fixation using FAA (formaldehyde-acetic acid-ethanol) for 90 min followed by secondary fixation in $1 \%$ osmium tetroxide for 30 min followed by dehydration with a graded ethanol series, mounted on aluminum stubs, and coated with gold-palladium. The element mapping was carried out at an operating voltage of $20 \mathrm{kV}$ and a working distance of $8.5 \mathrm{~mm}$. With the help of the INCA software, X-ray emission-based spectral peaks were analyzed. Electron-induced X-rays were detected by Si drift detector by measuring typical characteristic peak intensities. Once the intensities have been determined, a comparison is then made with standards of known composition with the INCA software applications, which uses filtered least squares (FLS) technique for this filtering and fitting.

\section{Estimation of $\mathrm{H}_{2} \mathrm{O}_{2}$}

Fresh roots $(0.1 \mathrm{~g})$ were homogenized in ice bath with $5 \mathrm{~mL}$ of $0.1 \%(\mathrm{w} / \mathrm{v})$ trichloroacetic acid (TCA). The homogenate tissue centrifuged at $4^{\circ} \mathrm{C}$ for $15 \mathrm{~min}$ at $12,000 \mathrm{rpm}$. An equal volume of the supernatant and potassium phosphate buffer $(\mathrm{pH} 7.0)$ taken, and $1 \mathrm{ml}$ of $1 \mathrm{M}$ potassium iodide added. $\mathrm{H}_{2} \mathrm{O}_{2}$ concentration was estimated at $390 \mathrm{~nm}$ on the absorbance of a standard curve and was expressed as nanomoles per gram FW (37). In situ $\mathrm{H}_{2} \mathrm{O}_{2}$ visualization in control and $\mathrm{Pb}$-treated roots was determined by $5 \mu \mathrm{M} 2^{\prime}, 7^{\prime}$-dichlorodihydrofluoresceindiacetate $\left(\mathrm{H}_{2} \mathrm{DCFDA}\right)$ dye with using a confocal microscope (Leica TCS SP2 AOBS Microscope, Germany) at $480 \mathrm{~nm}$ excitation and $520 \mathrm{~nm}$ emission wavelengths.

\section{Estimation of antioxidative enzymes activities}

Plant root samples $(1 \mathrm{~g})$ were homogenized in $50 \mathrm{mM}$ sodium phosphate buffer ( $\mathrm{pH}$ 7.8) for SOD, CAT and APX enzyme activities respectively. The homogenate was centrifuged at $10,000 \times \mathrm{g}$ for $20 \mathrm{~min}$ at $4{ }^{\circ} \mathrm{C}$. For APX assay; additional $2 \mathrm{mM}$ ascorbate was used in the homogenizing solution. The content of protein in the supernatant was determined according to the method of Lowry et al. 1951 (38) using a bovine serum albumin as a standard.

Superoxide dismutase (SOD, E.C. 1.15.1.1) activity was determined according to the method of Beauchamp and Fridovich 1971 (39). Samples containing $50 \mu \mathrm{g}$ of protein mixed with 50 $\mathrm{mM}$ sodium phosphate buffer ( $\mathrm{pH} 7.8$ ), $13 \mathrm{mM}$ methionine, $75 \mu \mathrm{M}$ nitroblue tetrazolium (NBT), $0.1 \mathrm{mM}$ ethylenediaminetetraacetic acid (EDTA), and $2 \mu \mathrm{M}$ of riboflavin (added at last). After mixing, mixtures were illuminated for $15 \mathrm{~min}$ using sophisticated bulbs $(40 \mathrm{~W})$. The reaction mixture containing sample protein and incubated in the dark served as blank, while the reaction mixture without sample protein held under light served as positive control. The absorbance measured at $560 \mathrm{~nm}$. One unit of SOD activity is determined by the amount of protein required to inhibit $50 \%$ initial reduction of NBT under the light.
Catalase (CAT, E.C. 1.11.1.6) activity measured by consumption of $\mathrm{H}_{2} \mathrm{O}_{2}\left(\varepsilon=43.6 \mathrm{mM}^{-1} \mathrm{~cm}^{-1}\right)$ according to the method of Aebi 1984 (40). The reaction mixture contained $50 \mathrm{mM}$ sodium phosphate buffer ( $\mathrm{pH} 7.0$ ), $19 \mathrm{mM} \mathrm{H}_{2} \mathrm{O}_{2}$ and $100 \mu \mathrm{g}$ of protein in a final volume of $3 \mathrm{~mL}$. The oxidation of $\mathrm{H}_{2} \mathrm{O}_{2}$ determined the activity at $240 \mathrm{~nm}$.

Ascorbate peroxidase (APX,E.C. 1.11.1.11) was assayed by the method of Nakano and Asada 1981 (41). The cocktail contained $50 \mathrm{mM}$ sodium phosphate buffer ( $\mathrm{pH} 7.0$ ), $0.5 \mathrm{mM}$ ascorbic acid, $250 \mathrm{mM} \mathrm{H}_{2} \mathrm{O}_{2}$ and $50 \mu \mathrm{g}$ of protein. The activity recorded as a decrease in the absorbance at $290 \mathrm{~nm}$ and the amount of ascorbate oxidized was calculated from the molecular extinction coefficient $\varepsilon=2.8 \mathrm{mM}^{-1} \mathrm{~cm}^{-1}$.

Guaiacol peroxidase (POD, E.C. 1.11.1.7) was determined using Putter 1974 (42). The cocktail mixture contained $50 \mathrm{mM}$ sodium phosphate buffer ( $\mathrm{pH} 7.0$ ), $20 \mathrm{mM}$ guaiacol solution, $12 \mathrm{mM} \mathrm{H}_{2} \mathrm{O}_{2}$ and $50 \mu \mathrm{g}$ of protein. The activity recorded as change in the absorbance at $436 \mathrm{~nm}$ and the amount of guaiacol was calculated using $\varepsilon=25.5 \mathrm{mM}^{-1} \mathrm{~cm}^{-1}$

Monodehydroascorbate reductase (MDAR, E.C. 1.6.5.4) was assayed by monitoring NADPH oxidation at $340 \mathrm{~nm}$ (43). The cocktail ( $3 \mathrm{~mL}$ ) contained $50 \mathrm{mM}$ sodium phosphate buffer ( $\mathrm{pH}$ 6.0), $0.1 \mathrm{mM}$ NADPH, $2.5 \mathrm{mM}$ ascorbic acid and enzyme extract equivalent to $100 \mu \mathrm{g}$ of protein. The activity began with the addition of 4 units of ascorbate oxidase $\left(\varepsilon=6.2 \mathrm{mM}^{-1} \mathrm{~cm}^{-1}\right)$.

\section{Glutathione estimation}

Total glutathione (GSH and GSSG) content was determined fluorometrically by following the method of Hissin and Hiff 1976 (44). Fresh roots ( $0.5 \mathrm{~g}$ ) was ground in $4 \mathrm{~mL}$ of $0.1 \mathrm{M}$ sodium phosphate-EDTA buffer ( $\mathrm{pH} 8.0$ ) containing $25 \% \mathrm{H}_{3} \mathrm{PO}_{3}$. The homogenate was centrifuged at $10,000 \mathrm{~g}$ for $20 \mathrm{~min}$ at $4{ }^{\circ} \mathrm{C}$. Final reaction mixture $(2.0 \mathrm{ml})$ contained $100 \mu \mathrm{l}$ of the diluted supernatant, $1.8 \mathrm{ml}$ of phosphate-EDTA buffer and $100 \mu \mathrm{l}$ of O-phthaladehyde $\left(1 \mathrm{mgml}^{-1}\right)$. After thorough mixing and incubating at room temperature for $15 \mathrm{~min}$, the solution was taken in a quartz cuvette measured after excitation at $350 \mathrm{~nm}$, and the fluorescence at $420 \mathrm{~nm}$ in a Hitachi spectrofluorimeter F-4010. Estimation of GSSG, using the procedure outlined for GSH assay, except that $0.1 \mathrm{~N} \mathrm{NaOH}$ used as diluents rather than phosphate-EDTA buffer. Total GSH and GSSG in roots calculated from the standard curve.

Glutathione reductase (GR, E.C. 1.6.4.2) determined by modifying the method of Jiang and Zhang 2001 (45). The cocktail mixture contained $25 \mathrm{mM}$ sodium phosphate buffer $(\mathrm{pH}$ 7.5), $3 \mathrm{mM} \mathrm{MgCl}, 10 \mathrm{mM}$ GSSG, and $1 \mathrm{mM} \mathrm{NADPH}$ in a total volume of $3 \mathrm{ml}$. The reaction started by addition of enzyme extract containing $50 \mu \mathrm{g}$ protein and GR activity monitored as NADPH oxidation $\left(\varepsilon=6.2 \mathrm{mM}^{-1} \mathrm{~cm}^{-1}\right)$ by the decrease in absorbance at $340 \mathrm{~nm}$.

\section{Statistical analysis}

The experiments were in triplicate, and the mean values \pm standard error (SE) was reported in figures. The data analysis was carried out by analysis of variance (ANOVA) and Tukey 

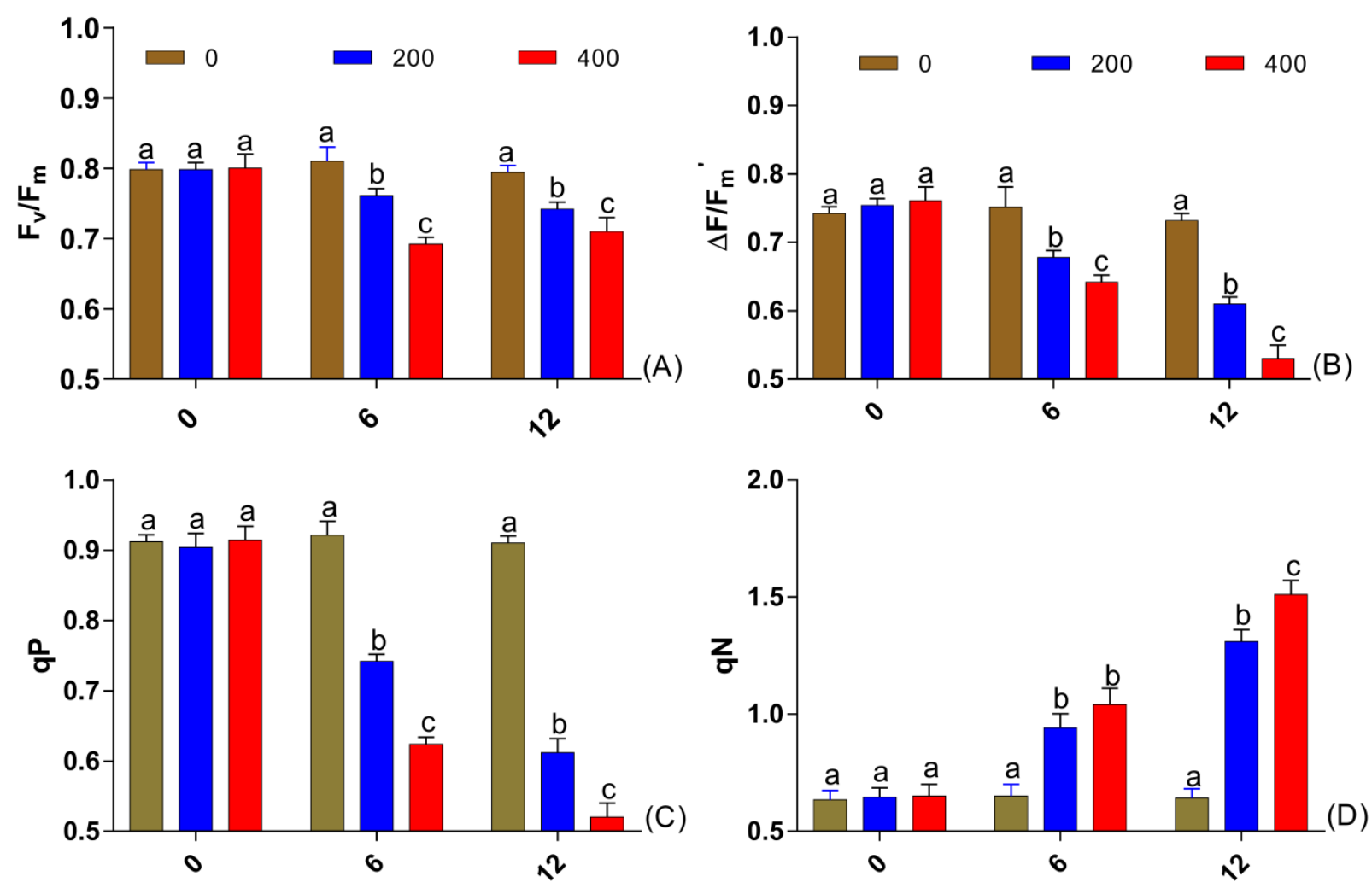

No. of days

No. of days

Figure 1. Changes in (A) Maximal photochemical efficiency $\left(F_{v} / F_{m}\right)$, (B) Effective quantum yield $\Delta F / F_{m}{ }^{\prime}$, (C) Photochemical quenching $(\mathrm{qP})$ and $(\mathrm{D})$ Non-photochemical quenching $(\mathrm{qN})$ in leaves of $R$. communis after 12 days of Pb treatment. Capped bar above represents mean \pm SE of three individual replicates. Different lower-case letters on bars indicate significant $(p<0.05)$ differences among treatments using Tukey HSD test.

multiple comparison tests using Graph pad prism (6.0) that accounted statistical differences at $(\mathrm{p} \leq 0.05)$ between each treatment and denoted by different letters.

\section{Results}

\section{$\mathrm{Pb}$ induced changes in chlorophyll fluorescence}

Chlorophyll fluorescence exhibited a dramatic change in $\mathrm{Pb}$ stressed leaves compared to control. Experimental findings of maximal photochemical efficiency $\left(\mathrm{F}_{\mathrm{v}} / \mathrm{F}_{\mathrm{m}}\right)$ exhibited a linear decline in all $\mathrm{Pb}$ treatments. The decrease in $\mathrm{F}_{\mathrm{v}} / \mathrm{F}_{\mathrm{m}}$ were observed at $200 \mathrm{uM}(7 \%)$ and $400 \mathrm{uM} \mathrm{Pb}(15 \%)$ for 6 days and $200 \mathrm{uM}(7 \%)$ and $400 \mathrm{uM} \mathrm{Pb}(11 \%)$ for 12 days time interval compared to control respectively (Fig.1A). Regarding chlorophyll, a fluorescence the effective quantum yield $\left(\Delta \mathrm{F} / \mathrm{F}_{\mathrm{m}}{ }^{\prime}\right)$ and photochemical quenching $(\mathrm{qP})$ were similar and reduced in leaves exposed to $\mathrm{Pb}$ treatments. The decrease in $\Delta \mathrm{F} / \mathrm{F}_{\mathrm{m}}{ }^{\prime}$ values for $200 \mathrm{uM}$ and $400 \mathrm{uM} \mathrm{Pb}$ is $11 \%$ and $15 \%$ for 6 days and $17 \%$ and $28 \%$ for 12 days time interval with respect to control
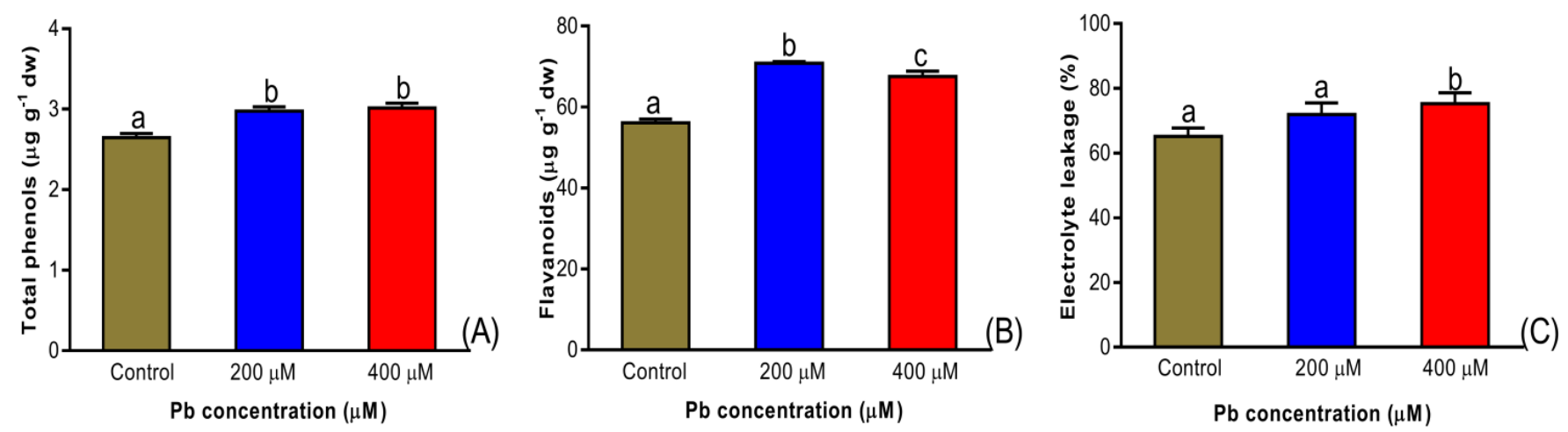

Figure 2. (A) Total phenolic content, (B) Flavonoids and (C) Electrolyte leakage in roots of $R$. communis after 10 days of Pb treatment. Capped bar above represents mean \pm SE of three individual replicates. Different lower-case letters on bars indicate significant $(p<0.05)$ differences among treatments using Tukey HSD test. 


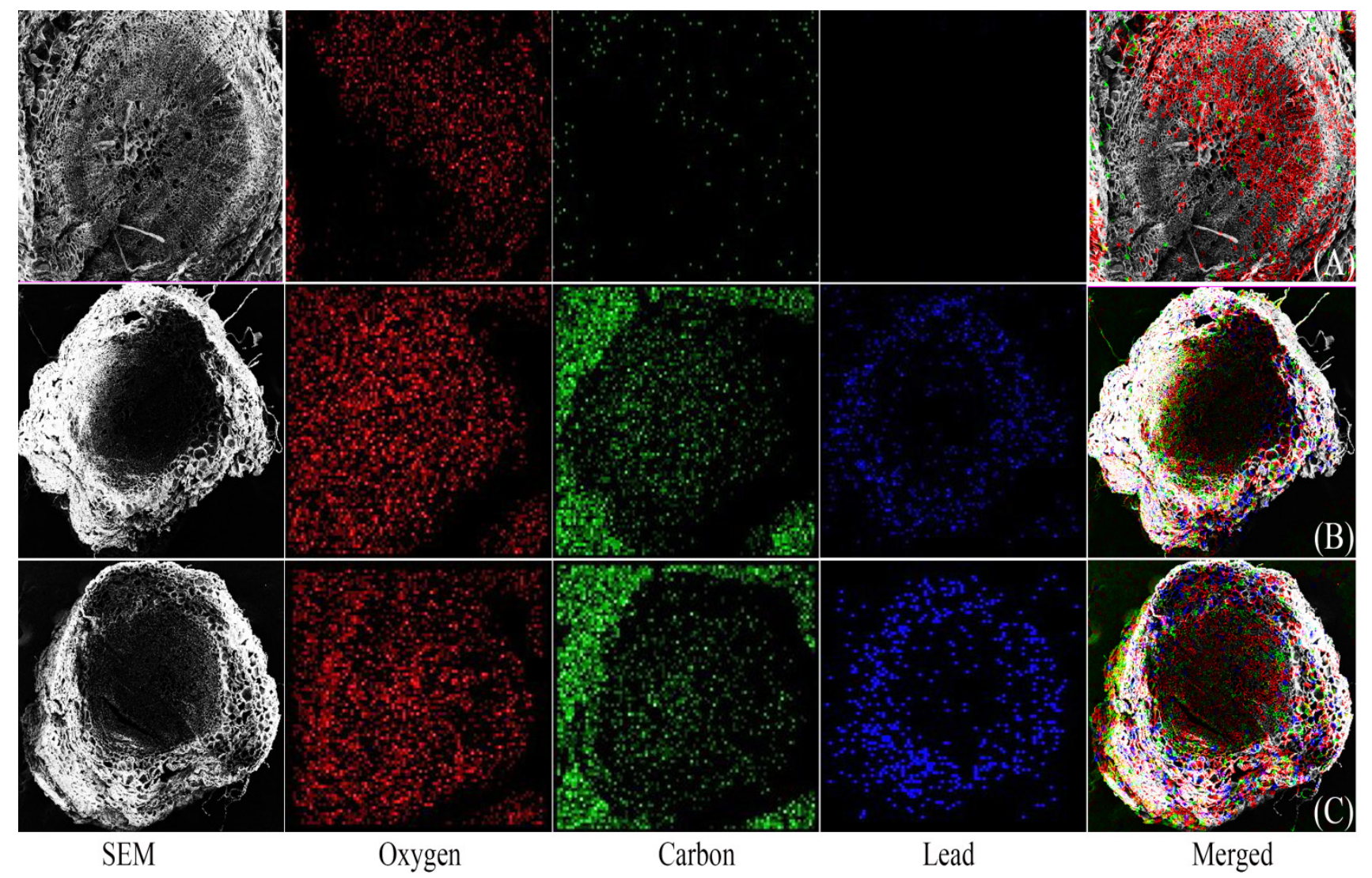

Figure 3. Elemental mapping profile of transverse section of root of $R$. communis, Control (A), $200 \mu \mathrm{M}(\mathrm{B})$ and $400 \mu \mathrm{M}(\mathrm{C}) \mathrm{using} \mathrm{FE}-$ SEM/EDS.

(Fig.1B). The tendency of photochemical quenching $(\mathrm{qP})$ in leaf decreased significantly at 200 and $400 \mathrm{uM} \mathrm{Pb}$, which was accounted for $20 \%$ and $33 \%$ for 6 days and $33 \%$ and $43 \%$ for 12 days time interval concerning control treatment (Fig. 1C). On the other hand linear increase in non-photochemical quenching (qN) was observed at $200 \mathrm{uM}$ and $400 \mathrm{uM}$ is $44 \%$ and $60 \%$ for 6 days respectively, with a concurrent increase of $104 \%$ and $135 \%$ for 12 days than compared to corresponding control respectively (Fig. 1D).

\section{Total phenols, flavonoids and electrolyte leakage}

An enhanced phenolic content in the leaves of castor bean was observed after 10 days of $\mathrm{Pb}$ treatment (Fig. 2A). The phenolic content was increased by $112.5 \%$ and $113.9 \%$ in $200 \mu \mathrm{M}$ and $400 \mu \mathrm{M}$ with respect to control. Similarly, total flavonoids content was also increased by $126.12 \%$ in $200 \mu \mathrm{M}$ and $120.33 \%$ in $400 \mu \mathrm{M}$ as compared to control respectively (Fig. 2B). The electrolyte leakage in the leaves of $R$. communis increased gradually with the increase in metal concentration. The ion leakage was $65.18 \%$ for control while it was $71.95 \%$ for $200 \mu \mathrm{M}$ and $75.22 \%$ for $400 \mu \mathrm{M}$ respectively after 10 days of $\mathrm{Pb}$ treatment (Fig. 2C).

Lead-induced structural modification and elemental analysis Scanning electron microscope (SEM) analysis data revealed $\mathrm{Pb}$ treatments (control (A), $200 \mu \mathrm{M}$ (B) and $400 \mu \mathrm{M}(\mathrm{C})$ ) altered the root integrity, pore formation and anatomical surfaces (Fig. 3). SEM micrograph of root showed that $\mathrm{Pb}$ caused rupture in root rhizoodermis and outer cortex which reduces nutrient uptake to the aerial part of the plant. Results of Energy Dispersive Spectroscopy showed the atomic percentage and chemical characteristics of the tissue (Table 1). Elemental mapping was performed for the transverse section of 0,200 and $400 \mu \mathrm{M} \mathrm{Pb}$ treated root samples. X-ray microanalysis revealed the presence of $\mathrm{Pb}$ in both the treated roots (Fig. 4A-C). Qualitative percentage composition showed deposition of elements oxygen $(\mathrm{O})$, carbon $(\mathrm{C})$ and lead $(\mathrm{Pb})$ in 200 and $400 \mu \mathrm{M}$ treated root compared to control respectively. The atomic percentage of carbon is increasing, and oxygen is decreasing upon dose dependent increase of $\mathrm{Pb}$ concentration.

\section{$\mathrm{H}_{2} \mathrm{O}_{2}$ estimation and visualization}

Spectrophotometric estimation along with histochemical visu-

Table 1. Analysis of atomic percentage of elements by energy dispersive spectroscopy (EDS) in transverse section roots of $R$. communis treated with 0,200 and $400 \mu \mathrm{M}$ of $\mathrm{Pb}$ for 10 days.

\begin{tabular}{|l|c|c|c|}
\hline \multicolumn{4}{|c|}{ Atomic \% of elements in roots of castor plants } \\
\hline Element & Control & $200 \mu \mathrm{M} \mathrm{Pb}$ & $\mathbf{4 0 0} \boldsymbol{\mu M ~ P b}$ \\
\hline Oxygen & 41.52 & 39.77 & 32.00 \\
\hline Carbon & 58.48 & 59.78 & 67.55 \\
\hline Lead & ND & 0.45 & 0.45 \\
\hline
\end{tabular}



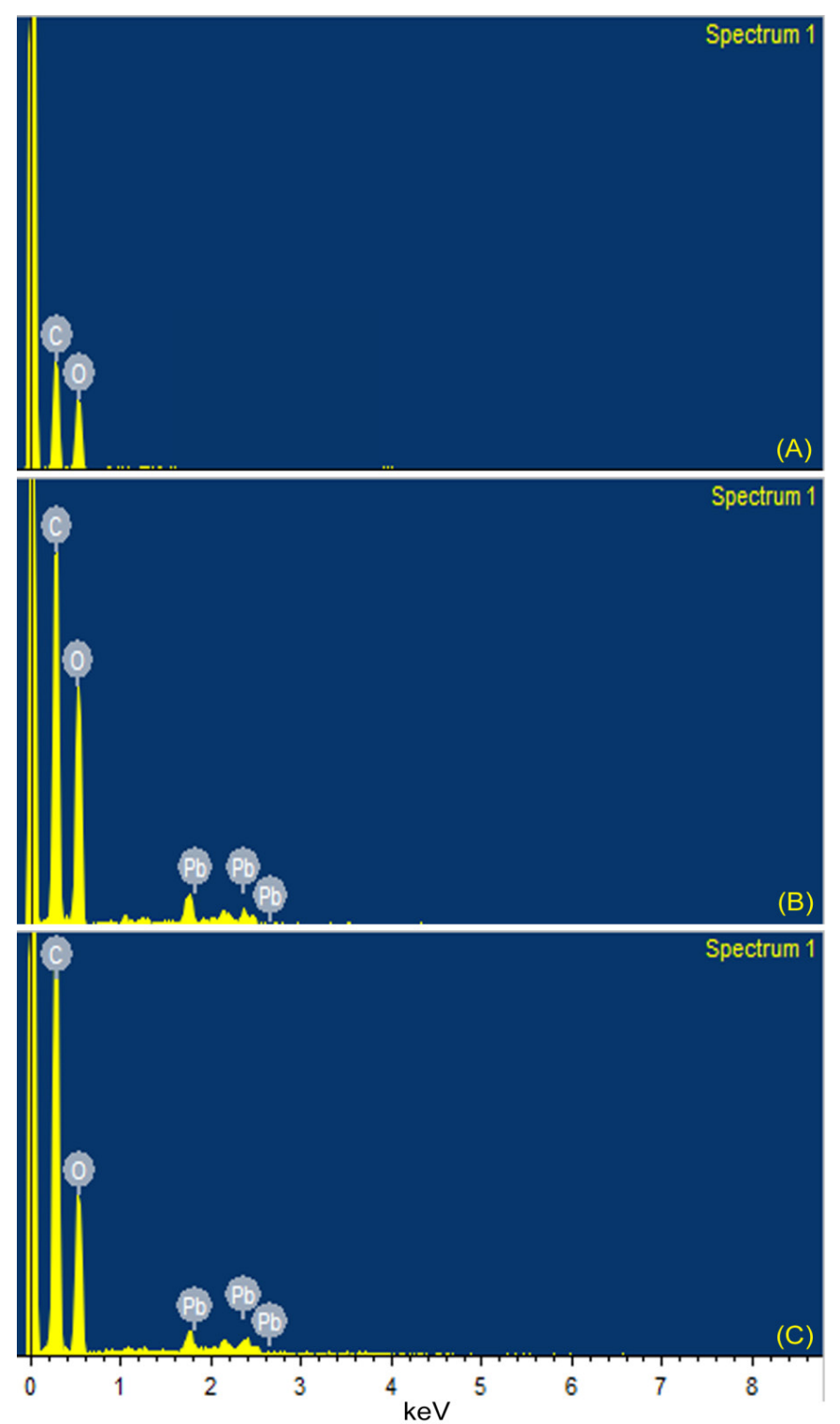

Figure 4. Energy dispersive X-ray spectral peak profile of R. com-

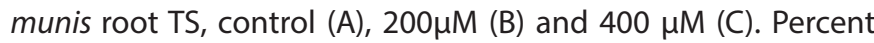
weight elemental composition of the imaged area for the Ricinus root using EDS.

alization in the root tissue clearly indicates the dose-dependent production of $\mathrm{H}_{2} \mathrm{O}_{2}$ upon treatment with $\mathrm{Pb}$ (Fig. 5A). Confocal results revealed that maximum fluorescence was observed at $400 \mu \mathrm{M}$ Pb-treated root followed by $200 \mu \mathrm{M}$ which signify maximum production of $\mathrm{H}_{2} \mathrm{O}_{2}$, while no fluorescence was seen at control (Fig. 5B). This data is corroborated with the $\mathrm{H}_{2} \mathrm{O}_{2}$ results obtained spectrophotometrically.

\section{Lead induced changes in antioxidant enzyme activities}

Increase concentration of SOD was observed with increasing concentration of $\mathrm{Pb}$ treatment $\left(\mathrm{R}^{2}=0.998\right.$; Fig. 6A). The high-

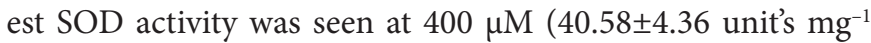

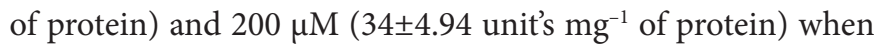
compared to the control $\left(25.50 \pm 1.60\right.$ unit's $\mathrm{mg}^{-1}$ of protein) respectively. Similarly, catalase also showed a dose-dependent increase in $\mathrm{Pb}$-treated roots (Fig. 6B). The CAT activity in roots

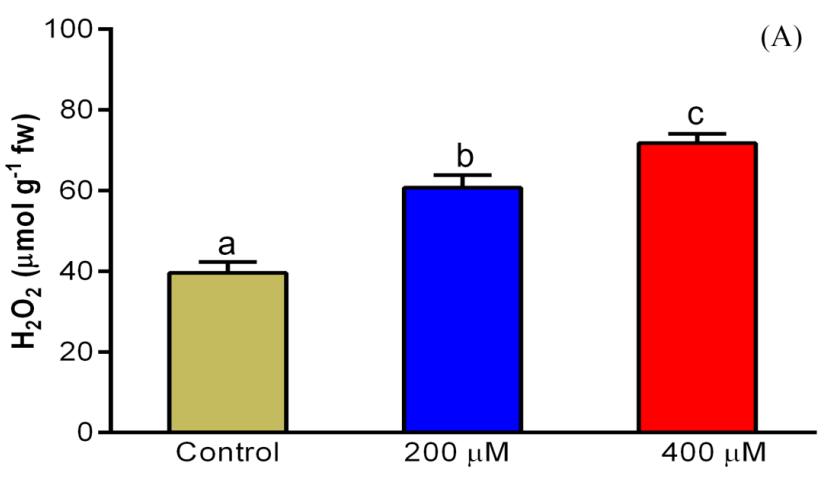

Pb concentration $(\mu M)$

(B)

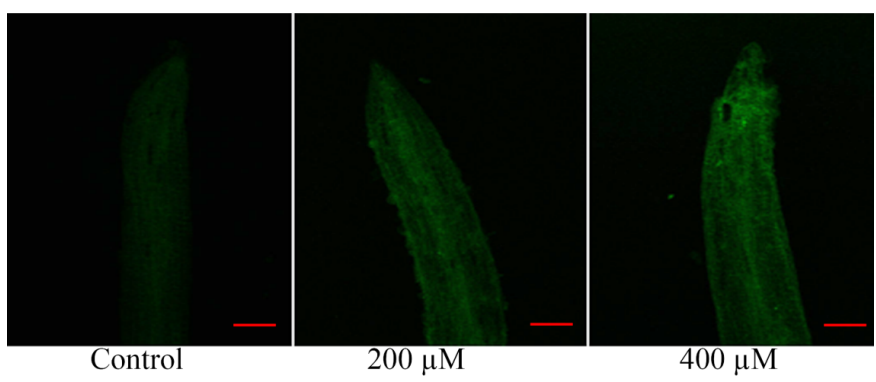

Figure 5. (A) $\mathrm{H}_{2} \mathrm{O}_{2}$ production in $R$. communis roots after 10 days of $\mathrm{Pb}$ treatment. Capped bar above represents mean $\pm \mathrm{SE}$ of three individual replicates. Different lower-case letters on bars indicate significant $(p<0.05)$ differences among treatments using Tukey HSD test. (B) Confocal micrograph images of histochemical visualization of $\mathrm{ROS}\left(\mathrm{H}_{2} \mathrm{O}_{2}\right)$ in root tip of $\mathrm{Pb}$ treated roots $($ bar $=300 \mu \mathrm{M})$.

increased significantly at $200 \mu \mathrm{M}\left(0.73 \pm 0.14 \mu \mathrm{mol} \mathrm{min}{ }^{-1} \mathrm{mg}^{-1}\right.$

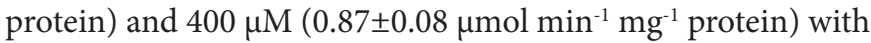
respect to control $\left(0.47 \pm 0.13 \mu \mathrm{mol} \mathrm{min}{ }^{-1} \mathrm{mg}^{-1}\right.$ protein). APX concentrations of $\mathrm{Pb}$-treated root samples showed a decline in activity compared to the control. The decrease in activities was observed at $200 \mu \mathrm{M}\left(115.5 \pm 3.19 \mu \mathrm{mol} \mathrm{min}^{-1} \mathrm{mg}^{-1}\right.$ protein $)$ and $400 \mu \mathrm{M}\left(108.5 \pm 8.96 \mu \mathrm{mol} \mathrm{min}^{-1} \mathrm{mg}^{-1}\right.$ protein $)$ compared to control $\left(121 \pm 3.69 \mu \mathrm{mol} \mathrm{min}{ }^{-1} \mathrm{mg}^{-1}\right.$ protein) respectively.

MDAR declined in its activity in Pb-treated root samples. The decrease in activity was observed at $200 \mu \mathrm{M}(5.16 \pm 0.98$ $\mu \mathrm{mol} \mathrm{min} \mathrm{mg}^{-1}$ protein) and $400 \mu \mathrm{M}\left(4.58 \pm 1.18 \mu \mathrm{mol} \mathrm{min}{ }^{-1}\right.$ $\mathrm{mg}^{-1}$ protein) when compared to control $\left(6.45 \pm 0.74 \mu \mathrm{mol} \mathrm{min}^{-1}\right.$ $\mathrm{mg}^{-1}$ protein) respectively. Our results showed that GPX activity at $200 \mu \mathrm{M}\left(73.70 \pm 3.98 \mu \mathrm{mol} \mathrm{min}{ }^{-1} \mathrm{mg}^{-1}\right.$ protein $)$ enhanced its activity and further decreased at $400 \mu \mathrm{M}(44.21 \pm 7.50 \mu \mathrm{mol}$ $\mathrm{min}^{-1} \mathrm{mg}^{-1}$ protein) with respect to the control $(60.28 \pm 5.94$

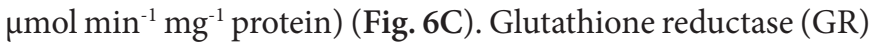
activity increased significantly upon an increase in dose-dependent $\mathrm{Pb}$ concentration. The increased GR was observed for $200 \mu \mathrm{M}\left(8.96 \pm 0.49 \mu \mathrm{mol} \mathrm{min} \mathrm{mg}^{-1}\right.$ protein $)$ and $400 \mu \mathrm{M}$ $\left(10.07 \pm 0.30 \mu \mathrm{mol} \mathrm{min}{ }^{-1} \mathrm{mg}^{-1}\right.$ protein $)$ in comparison to control $\left(6.45 \pm 0.57 \mu \mathrm{mol} \mathrm{min}{ }^{-1} \mathrm{mg}^{-1}\right.$ protein) respectively (Fig. 6D).

\section{Lead induced changes in Glutathione}

$\mathrm{Pb}$ caused significant changes in reduced (GSH) and oxidized glutathione (GSSG). The regression analysis showed as the in- 


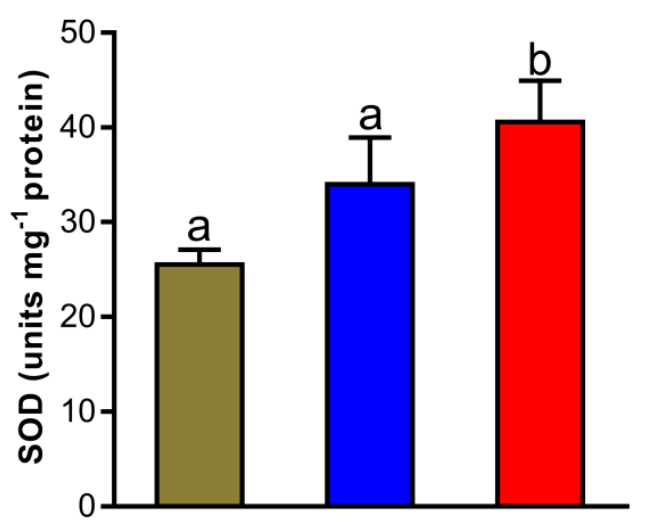

(A)
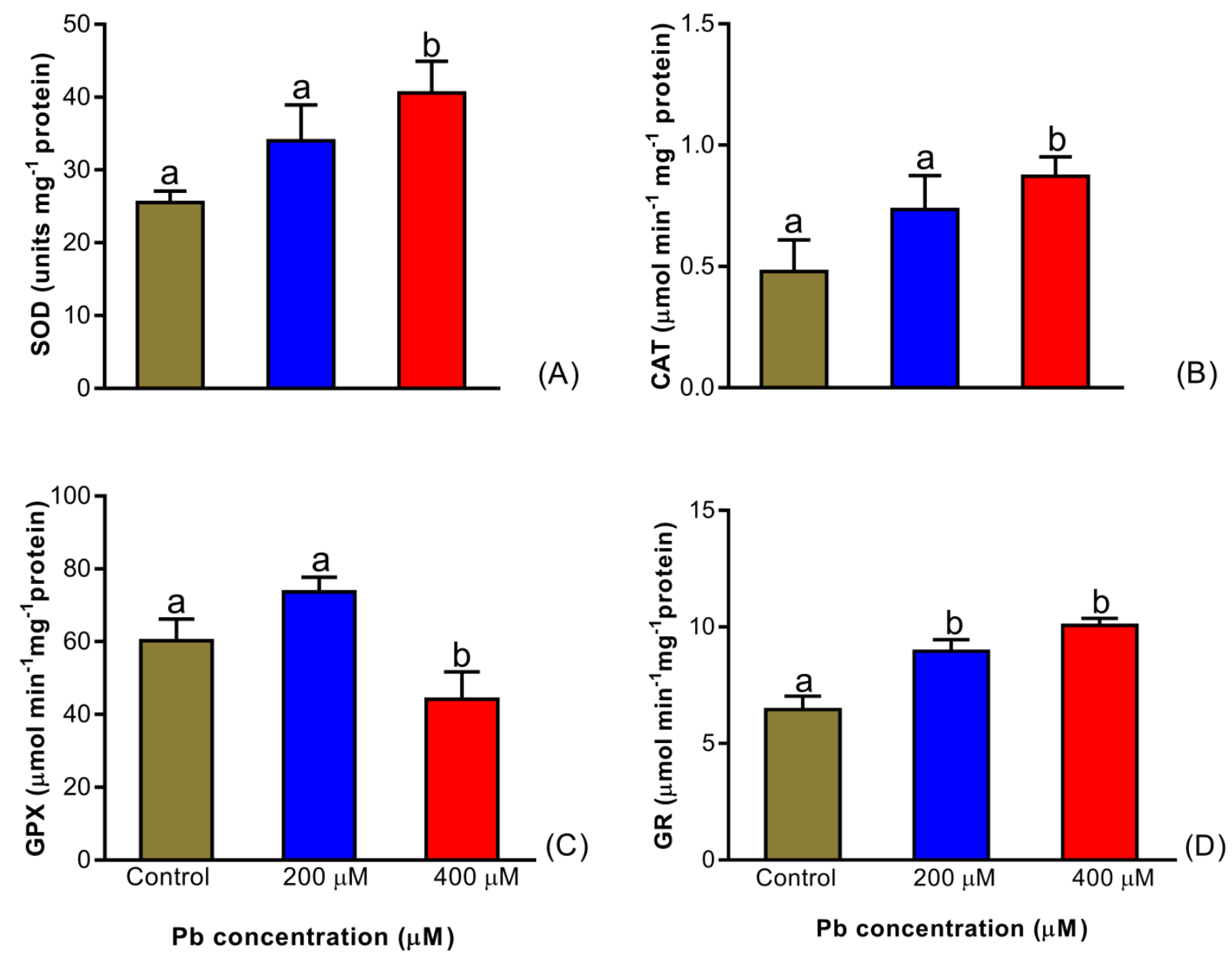

Figure 6. Dose-dependent responses in antioxidative enzymes (A) Superoxide dismutase (SOD), (B) Catalase (CAT), (C) Guaiacol peroxidise (GPX) and (D) Glutathione reductase (GR) activities in $R$. communis roots after 10 days of Pb treatment. Capped bar above represents mean \pm SE of three individual replicates. Different lower-case letters on bars indicate significant $(p<0.05)$ differences among treatments using Tukey HSD test.
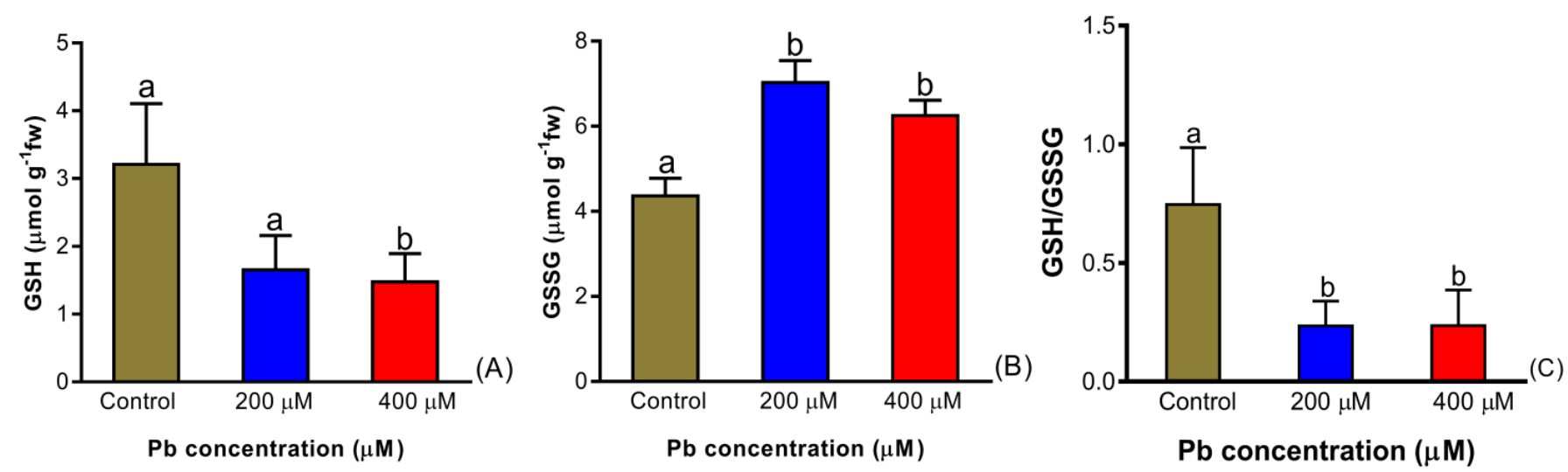

Figure 7. Levels of (A) Glutathione reduced (GSH), (B) Glutathione oxidized (GSSG) and (C) GSH/GSSG ratio in roots of R. communis after 10 days of $\mathrm{Pb}$ treatment. Capped bar above represents mean $\pm \mathrm{SE}$ of three individual replicates. Different lower-case letters on bars indicate significant $(p<0.05)$ differences among treatments using Tukey HSD test. 
creased concentration of $\mathrm{Pb}$ causes a decline in GSH values $\left(\mathrm{R}^{2}=0.980\right.$; Fig. 7A). GSH content in root tissue was found to decrease in all the $\mathrm{Pb}$ treatments. The decline was observed at $200 \mu \mathrm{M}$ and $400 \mu \mathrm{M}$, which accounted for $51.40 \%$ and $45.79 \%$ compared to the control. On the other hand, GSSG level was gradually increased as the external $\mathrm{Pb}$ concentration increased $\left(R^{2}=0.961\right.$; Fig. 7B). The significant induction in GSSG content was observed at $200 \mu \mathrm{M}(161.07 \%)$ and $400 \mu \mathrm{M}(143.34 \%)$ when compared to control. A decrease in GSH/GSSG redox ratio was observed upon lead treatment (Fig. 7C).

\section{Discussion}

In the present study, $\mathrm{Pb}$ nitrate is used as a $\mathrm{Pb}$ donor to assess the effects on $R$. communis. Nitrates are the major sources of inorganic nitrogen taken up by roots of higher plants. It is mobile in xylem and stored in the vacuoles of roots, shoots and storage organs. Plants use nitrates as a supply of nitrogen, which is needed to make its own amino acids for protein synthesis and healthy growth. Increase in nitrate, leads to increase in osmotic concentration of the soil solution which leads plant to wilt. Too much application of nitrates in fields leads to soil leaching results algal growth and finally eutrophication (46). In the present study, roots absorb high concentration of $\mathrm{Pb}$ than stem and leaves. The level of $\mathrm{Pb}$ in aerial parts of plant decreases with the increase of distance from the origin. This occurs due to the greater localization of metal within the cell wall or some other parts of the root. $\mathrm{Pb}$ alters the chlorophyll fluorescence and has a negative impact on photosynthesis and activity of both PSII and PSI. It results in the inhibition of photosynthetic pigments biosynthesis, inhibition of electron transport and energy transfer between $\mathrm{OEC}$ and PSII-reaction center (RC). The effect of $\mathrm{Pb}$ on fluorescence parameters such as $\mathrm{F}_{\mathrm{v}} / \mathrm{F}_{\mathrm{m}}, \Delta \mathrm{F} / \mathrm{F}_{\mathrm{m}}{ }^{1}, \Phi_{\mathrm{PSII}}, \mathrm{qP}$ and $\mathrm{qN}$ has been documented in different plant species $(47,48)$ Our results showed a decline in Chl fluorescence induction curves when all the PSII-RC is closed. The decrease in $\mathrm{F}_{\mathrm{m}}$ expresses the inhibition on the donor side of PSII when all the $\mathrm{Q}_{\mathrm{A}}$ molecules are in reduced condition, is due to unavailability of electrons to provide for the accumulation of photoreduced $Q_{A}$. Reduction in qP shows the $\mathrm{Pb}$ interference in the utilization of ATP and NADPH generated during the light reaction. During abiotic stress, phenolic compounds and flavonoids act as metal chelators by directly scavenging the ROS and neutralizing free radicals (49). A gradual increase in electrolyte leakage was observed in 200 and $400 \mu \mathrm{M} \mathrm{Pb}$ treatments. Electrolyte leakage indicates a loss in membrane permeability which often interferes with lipid bilayers under $\mathrm{Pb}^{2+}$ ions toxicity. It causes leakage of $\mathrm{K}^{+}$ions and led to deformed cell membranes $(50,14)$. The increase in phenolic content showed no significant difference in both the $\mathrm{Pb}$ treatments with respect to control. Phenolic compounds act as a substrate for different peroxidases were the first line of defense against $\mathrm{Cu}$ stress in red cabbage (51) and Cd treatment in roots of maize (52). Phytophenolics donate electrons to guaiacol type peroxidises ( $\mathrm{GuPXs}$ ) for detoxifications of $\mathrm{H}_{2} \mathrm{O}_{2}$ under stress condition (53). Flavonoids have the ability to capture free rad- ical ions by donation of phenolic hydrogen atoms and showed antioxidant activity. Accumulation of these compounds might be one of the strategies that plant use against oxidative stress which protects the plant from damage and increases the stability of cell membranes. Increased content of total phenols (0.936) and flavonoids (0.722) showed good correlation with $\mathrm{H}_{2} \mathrm{O}_{2}$ production.

Roots are the major characteristic sites for metal accumulation. In our experiment, we noticed that $\mathrm{Pb}$ treatment resulted in a change in root morphology leading to deformed structure compared to control. Rupture in root rhizoodermis, and outer cortex has been reported in Talinum triangulae exposed to $\mathrm{Pb}$ and cowpea (Vigna unguiculata) exposed to $\mathrm{Al}, \mathrm{Cu}$, and $\mathrm{La}$ (54). Further analysis of root TS revealed that most of the $\mathrm{Pb}$ were accumulated within the cell wall and vacuoles (Fig. 3AC). The loss of cell shape and a decrease in intercellular spaces have also been observed in the Pb-treated plant over the control plant, which may inhibit the translocation or uptake of nutrient elements, $\mathrm{Pb}$, and water from roots to stems and above ground parts of the plant. The EDS data showed the distribution of $\mathrm{Pb}$ in the roots of $R$. communis treated samples. High concentration of $\mathrm{Pb}$ causes an imbalance of mineral nutrients within the tissues of growing plants (55). It blocks the entry of certain divalent cations $\left(\mathrm{Zn}^{2+}, \mathrm{Mn}^{2+}, \mathrm{Fe}^{2+}, \mathrm{Mg}^{2+}, \mathrm{Ca}^{2+}\right.$ and $\left.\mathrm{Cu}^{2+}\right)$. Our results showed a decrease in the atomic percentage of $\mathrm{O}$ and increase in $\mathrm{C}$ in the $\mathrm{Pb}$-treated samples compared to control. This is confirmed in our previous study by the significant decrease in the atomic percentage of nutrient elements in roots of $R$. communis (31). A similar result was obtained in Brachiaria decumbens (56) and Spirodela polyrhiza (57) caused reduction of nutrients in shoot tissue. The study showed lead uptake has a negative effect on the mineral nutrients of $R$. communis roots. The decrease of nutrients in the presence of lead may be due to the size of the metal ion radii or changes in membrane enzyme activities. The $\mathrm{Na}$ or $\mathrm{K} / \mathrm{Ca}$ ion ratios are important for plant growth, development and metabolic processes (58). Thus, we postulate the decrease in nutrients atomic percentage is due to the altered growth, negative interactions between nutrients and competitive interference of $\mathrm{Pb}$ within the plant.

$\mathrm{H}_{2} \mathrm{O}_{2}$ production increases with increased concentration of lead. 2',7'-dichlorodihydrofluorescein diacetate ( $\left.\mathrm{H}_{2} \mathrm{DCFDA}\right)$ is chemically reduced form of fluorescein which is used as an indicator for reactive oxygen species (ROS). From our study, we can suggest that in-vivo $\mathrm{H}_{2} \mathrm{O}_{2}$ analysis through histochemical visualization was fast and reliable. The dose-dependent increase in histochemically visualized cellular $\mathrm{H}_{2} \mathrm{O}_{2}$ is on good governance with the spectrophotometrically measured $\mathrm{H}_{2} \mathrm{O}_{2}$ in roots of $R$. communis. $\mathrm{Pb}$ toxicity induces oxidative damage to membrane lipids and proteins through the generation of ROS. It acts as a signal transduction under metal stress and regulates the plant defense system (59). It has been reported that the disturbance in electron transport chain in the membrane is the primary cause for generation of $\operatorname{ROS}(60,53)$. Previous data also supported the higher production of $\mathrm{H}_{2} \mathrm{O}_{2}$ in T. aestivum (10) and T. triangulae (53); Armeria maritima (61); Coronopus 
didymus (14). Arabidopsis mutants showed $\mathrm{Pb}$ hypersensivity and elevated levels of $\mathrm{H}_{2} \mathrm{O}_{2}$ compared to wild type plants (62).

Plants have evolved an efficient defense system which includes both enzymatic and non-enzymatic that helps to maintain redox potential and withstand against oxidative stress. $\mathrm{Pb}$ toxicity activates certain enzymes by modulating gene expression or by restricting the activity of the enzyme inhibitors (3). Our results showed the differential response of both enzymatic, i.e., SOD, CAT, APX, POD and non-enzymatic,i.e., GSH and GSSG antioxidants in Pb-treated root samples. Superoxide dismutase, a metalloenzyme present in different cell compartments, is considered to be the first line of defense against oxidative stress. It dismutases $\mathrm{O}^{2-}$ to $\mathrm{O}_{2}$ and then to $\mathrm{H}_{2} \mathrm{O}_{2}$ that is further reduced to $\mathrm{H}_{2} \mathrm{O}$ by the activities of CAT and GPX and maintain superoxide radicals at steady state levels $(63,15)$. Catalase detoxifies $\mathrm{H}_{2} \mathrm{O}_{2}$ directly in the cell. Increased effect of catalase is due to direct effect of $\mathrm{Pb}$ and increased production of $\mathrm{H}_{2} \mathrm{O}_{2}$ through SOD. Increased activity of SOD and CAT showed good correlation with increased ROS production (0.988) and (0.999) respectively. Previous studies showed during Pb-stress condition, an increased activity of CAT in Spirodela polyrhiza (54), SOD in Cajanus cajan (64) and CAT and SOD in Triticum aestivum (10) have been observed. Ascorbate peroxidises (APX) a key enzyme of Halliwell-Asada enzyme pathway. It reacts directly with ROS molecules as well as acts as a secondary antioxidant operating both in chloroplast and cytosol (65). In the present study decrease of ascorbate content attributed to oxidation of ascorbate into monodehydroascorbate (MDHA) with concomitant detoxification of $\mathrm{H}_{2} \mathrm{O}_{2}$ to water molecules $(66,67)$. In contrast to increasing APX during different $\mathrm{Pb}$ treatments, various studies have reported about decreased levels of APX in V. natans (68), Conzya candensis (69) and Brachiaria mutica \& Ricinus communis (15). A concentration-dependent up regulation in the activity of SOD (225\% and 136\%), CAT (44 and 30\%) and APX (1300 and 233\%) was reported in the roots and in the shoots, respectively of C.didymus over control plant (14). Concomitant changes in the activities of CAT, SOD and APX enzymes are liable for detoxification of ROS and amelioration of oxidative stress condition.

Glutathione (GSH) is one of the abundant intercellular non-protein thiols which maintain the cellular redox status. It acts as a chelating bioligand which counteracts the oxidative stress imposed by heavy metals in plants. The role of GSH and glutathione reductase (GR) in scavenging $\mathrm{H}_{2} \mathrm{O}_{2}$ is well established in Halliwei-Asada enzyme pathway (70). The results showed a decline in GSH and enhanced levels of GSSG content is a true indication of oxidative stress. The lower rate of GSH is attributed due to increase production of $\mathrm{H}_{2} \mathrm{O}_{2}$. Qiao et al. 2012 (54) in his study reported that S. polyrhiza when treated with $133 \mathrm{mg} \mathrm{L}^{-1} \mathrm{~Pb}$, showed 35\% reduction in GSH level. Several other researchers also reported $\mathrm{Pb}$ changes GSH level in different plant species like H. annuus (71), Brassica napus (72), Peganum harmala (11) and M. sativa (73). GSH acts as a shield from oxidative injury and initiates phytochelatins (components of non-protein thiols) by triggering phytochelatin synthetase. Phytochelatins further bind to $\mathrm{Pb}$ and carry them to the vacuole and detoxify them. The oxidized form of glutathione (GSSG) is readily converted to reduced form (GSH) by glutathione reductase (GR). GR is a member of flavoenzyme family which catalyzes the NADPH-dependent reduction. The results showed an increase in GR activity. Saleem et al. 2018 (13) reported that increasing concentration of $\mathrm{Pb}(300,600$ and $900 \mathrm{mg} \mathrm{kg}^{-1}$ ) gradually increased the activity of GR enzyme in sunflower which was accounted for $30 \%, 60 \%$, and $107 \%$ respectively. On the other hand decrease of GSH/GSSG ratios was observed due to a rapid reduction in GSH and induction in GSSG content during $\mathrm{Pb}$ treatment. Formation of $\mathrm{Pb}-\mathrm{GSH}$ complexes and $\mathrm{Pb}$-induced phytochelatin synthesis reduces $\mathrm{Pb}$ concentration and contributes to activation of stress-related responses in plant metabolism (3).

\section{Conclusion}

Considering our results, we can conclude that $\mathrm{Pb}$ accumulated in the Ricinus communis causes oxidative damage by increasing the production of ROS. The decrease in the atomic percentage of nutrients in $\mathrm{Pb}$-treated root supports the idea of avoidance mechanism. The increase in electrolyte leakage and non-enzymatic antioxidants such as phenols and flavanoids shows their adaptive role as a barrier in scavenging ROS and protecting the membrane damage. Confocal laser microscopy imaging along with spectrophotometric studies showed the elevated levels of ROS under dose-dependent increase of $\mathrm{Pb}$ concentration. High levels of antioxidative enzymes such as SOD, CAT, GPX, APX and MDAR showed good tolerance mechanism against $\mathrm{Pb}$ toxicity by detoxifying free radicals and preventing cell injury and tissue dysfunction. Alteration in glutathione levels and redox ratio of GSH/GSSG helps the plant in maintaining cellular homeostasis. These findings suggest the toxicity and tolerance strategy of Ricinus communis in coping up the oxidative stress under $\mathrm{Pb}$ toxicity. Further research on molecular aspects of $\mathrm{Pb}$ toxicity and micro-localization of metal in the tissue is yet to be elucidated.

\section{Abbrevations}

APX- Ascorbate peroxidase - CAT- Catalase - GR- Glutathione reductase - GSH - Glutathione (reduced) · GSSG- Glutathione (oxidized) . MDAR- Monodehydroascorbate reductase $\cdot$ ROS- Reactive oxygen species $\cdot$ SOD- Superoxide dismutase.

\section{Acknowledgements}

BRK grateful acknowledges the Rajiv Gandhi National Fellowship (RGNF-UGC).Thanks are due to the Head, Department of Plant Sciences, University of Hyderabad, for providing facilities.

\section{Conflict of Interest}

The authors declare that they have no conflicts of interest.

\section{Ethical Compliance}

This article does not contain any studies involving human participants or animals performed by any of the authors. 


\section{References}

1. Gupta DK, Huang HG, Corpas FJ. Lead tolerance in plants: strategies for phytoremediation. Environ. Sci. Pollut. Res., 2013; 20: 2150-2161.

2. Obiora SC, Chukwu A, Toteu SF, Davies TC. Assessment of heavy metal contamination in soils around lead (Pb)-zinc ( $\mathrm{Zn}$ ) mining areas in Enyigba, south-eastern Nigeria. J. Geol. Soc., 2016; 87: 453-462.

3. Kumar A and Prasad MNV. Plant-lead interactions: Transport, toxicity, tolerance, and detoxification mechanisms. Ecotoxicol. Environ. Saf. 2018; 166, 401-418.

4. Mroczek-Zdyrska M, Strubińska J, Hanaka A. Selenium improves physiological parameters and alleviates oxidative stress in shoots of lead-exposed Vicia faba L. minor plants grown under phosphorus-deficient conditions. J. Plant Growth Regul., 2016: 36; 186199.

5. Sorrentino MC, Capozzi F, Giordano S, Spagnuolo V. Genotoxic effect of $\mathrm{Pb}$ and $\mathrm{Cd}$ on in vitro cultures of Sphagnum palustre: an evaluation by ISSR markers. Chemosphere, 2017; 181: 208-215.

6. Ashraf $U$ and Tang $X$. Yield and quality responses, plant metabolism and metal distribution pattern in aromatic rice under lead $(\mathrm{Pb})$ toxicity. Chemosphere, 2017; 176: 141-155. doi:10.1016/j. chemosphere.2017.02.103.

7. Piwowarczyk B, Tokarz K, Muszyńska E, Makowski W, Jędrzejczyk R, Gajewski Z, Hanus-Fajerska E. The acclimatization strategies of kidney vetch (Anthyllis vulneraria L.) to Pb toxicity. Environ. Sci. Pollut. Res., 2018; 25: 19739-19752.

8. Morel JL, Mench $\mathrm{M}$, Guckert A. Measurement of $\mathrm{Pb}, \mathrm{Cu}$ and $\mathrm{Cd}$ Binding with Mucilage Exudates from Maize (Zea mays L.) Roots, Biol. Fertil. Soils, 1986; 2: 29-34.

9. Pourrut B, Shahid M, Dumat C, Winterton P, Pinelli E. Lead uptake, toxicity and detoxification in plants. Rev Environ Conta Toxicol, 2011; 213: 113-136.

10. Kaur G, Singh HP, Batish DR, Kohli RK. A time course assessment of changes in reactive oxygen species generation and antioxidant defense in hydroponically grown wheat in response to lead ions (Pb2+). Protoplasma, 2012; 249(4): 1091-1100. doi:10.1007/ s00709-011-0353-7

11. Mahdavian $\mathrm{K}$, Ghaderian $\mathrm{SM}$, Schat $\mathrm{H}$. Pb accumulation, $\mathrm{Pb}$ tolerance, antioxidants, thiols, and organic acids in metallicolous and non-metallicolous Peganum harmala L. under $\mathrm{Pb}$ exposure. Environ Exper Bot, 2016; 126: 21-31.

12. López-Orenes A, Dias MC, Ferrer MÁ, Calderón A, Moutinho-Pereira J, Correia C, Santos C. Different mechanisms of the metalliferous Zygophyllum fabago shoots and roots to cope with Pb toxicity. Environ. Sci. Pollut. Res., 2018; 25: 1319-1330.

13. Saleem M, Asghar HN, Zahir ZA, Shahid M. Impact of lead tolerant plant growth promoting rhizobacteria on growth, physiology, antioxidant activities, yield and lead content in sunflower in lead contaminated soil. Chemosphere, 2018; 195: 606-614.

14. Sidhu GPS, Singh HP, Batish DR, Kohli RK. Effect of lead on oxidative status, antioxidative response and metal accumulation in Coronopus didymus. Plant Physiol. Biochem., 2016; 105: 290-296.

15. Khan MM, Islam E, Irem S, Akhtar K, Ashraf MY, Iqbal J, Liu D. Pb-induced phytotoxicity in para grass (Brachiaria mutica) and castor bean (Ricinus communis L.): antioxidant and ultrastructural studies. Chemosphere, 2018; 200: 257-265.

16. Maldonado-Magana A, Favela-Torres E, Rivera-Cabrera F, Volke-Sepulveda TL. Lead bioaccumulation in Acacia farnesiana and its effect on lipid peroxidation and glutathione production. Plant Soil, 2011; 339(1-2): 377-389.

17. Kumar A, Majeti NVP. Proteomic responses to lead-induced oxidative stress in Talinum triangulare Jacq. (Willd.) roots: identification of key biomarkers related to glutathione metabolisms. Environ. Sci. Pollut. Res., 2014; 21: 8750-8764.

18. Kohli SK, Handa N, Bali S, Arora S, Sharma A, Kaur R, Bhardwaj R Modulation of antioxidative defense expression and osmolyte content by co-application of 24-epibrassinolide and salicylic acid in $\mathrm{Pb}$ exposed Indian mustard plants. Ecotoxicol. Environ. Saf, 2018; 147: 382-393.

19. Zhou F, Wang J, Yang N. Growth responses, antioxidant enzyme activities and lead accumulation of Sophora japonica and Platycladus orientalis seedlings under $\mathrm{Pb}$ and water stress. Plant Growth Regul, 2015; 75: 383-389.

20. Rodriguez E, da Conceição Santos M, Azevedo R, Correia C, Moutinho-Pereira J, Ferreira de Oliveira JMP, Dias MC. Photosynthesis light-independent reactions are sensitive biomarkers to monitor lead phytotoxicity in a Pb-tolerant Pisum sativum cultivar. Environ. Sci. Pollut. Res., 2015; 22: 574-585.

21. Marques MC, Nascimento CWA, da Silva AJ, Gouviea-Neto AS. Tolerance of an energy crop (Jatropha curcas L.) to zinc and lead assessed by chlorophyll fluorescence and enzyme activity. S Afr J Bot, 2017; 112: 275-282.

22. Kiran BR, Prasad MNV. Ricinus communis L. (Castor bean), a potential multi-purpose environ-mental crop for improved and integrated phyto-remediation. The Euro Biotech J, 2017a; 1(2): 1-16.

23. Olivares AR, Carrillo-González R, González-Chávez MCA, Hernández RMS. Potential of castor bean (Ricinus communis L.) for phytoremediation of mine tailings and oil production. J. Environ. Manag., 2013; 114: 316-323.

24. Kushwaha A, Hans N, Kumar S, Rani R. A critical review on speciation, mobilization and toxicity of lead in soil-microbe-plant system and bioremediation strategies. Ecotoxicol. Environ. Saf., 2018;147: 1035-1045.

25. Silva WR, da Silva FBV, Arauj PRM, do Nascimento. Assessing human health risks and strategies for phytoremediation in soils contaminated with $\mathrm{As}, \mathrm{Cd}, \mathrm{Pb}$, and $\mathrm{Zn}$ by slag disposal. Ecotoxicol. Environ. Saf., 2017; 144: 522-530.

26. Wei R, Guo Q, Yu G, Kong J, Okoli CP. Stable isotope fractionation during uptake and translocation of cadmium by tolerant Ricinus communis and hyperaccumulator Solanum nigrum as influenced by EDTA. Environ. Pol., 2018; 236: 634-644.

27. Yazdi M, Kolahi M, Kazemi EM, Barnaby AGB. Study of the contamination rate and change in growth features of lettuce (Lactuca sati$v a$ Linn.) in response to cadmium and a survey of its phytochelatin synthase gene. Ecotoxicol. Environ. Saf., 2019; 180: 295-308.

28. Huang G, Guo G, Yao S, Zhang N, Hu H. Organic Acids, Amino acids compositions in the root exudates and $\mathrm{Cu}$-accumulation in castor (Ricinus communis L.) under Cu Stress. Int J Phytoremediation, 2016; 18(1): 33-40.doi:10.1080/15226514.2015.1058333.

29. Celik $O$ and Akdas EY. Tissue specific transcriptional regulation of seven heavy metal stress-responsive miRNAs and their putative targets in nickel indicator castor bean ( $R$. communis L.) plants. Ecotoxicol. Environ. Saf., 2019; 170: 682-690.

30. Yang J, Yang J, Huang J. Role of co-planting and chitosan in phytoextraction of As and heavy metals by Pteris vittata and castor bean - A field case. Ecol. Eng., 2017; 109: 35-40.

31. Kiran BR, Prasad MNV. Responses of Ricinus communis L. (Castor bean, phytoremediation crop) seedlings to lead $(\mathrm{Pb})$ toxicity in hydroponics. Selcuk J Agr Food Sci, 2017b; 31(1): 73-80.

32. Boda RK, Prasad MNV, Suthari S. Ricinus communis L. (castor bean) as a potential candidate for revegetating industrial waste contaminated sites in peri-urban Greater Hyderabad: remarks on seed oil. Environ Sci Pollut Res, 2017; 24: 1-10. doi 10.1007/s11356-0179654-5

33. Hoagland DR and Arnon DI The water-culture method for growing plants without soil. Calif Agric Exp Stn Circ, 1950; 347: 1-32. doi:citeulike-article-id:9455435.

34. Singleton VL, Orthofer R, Larnuela-Raventos RM. Analysis of total phenols and other oxidation substrates and antioxidants by means of Folin-Ciocalteu reagent. Methods in Enzymology, 1999; 299: 152-178.

35. Zhishen J, Mengcheng T, Jianming W. The determination of flavanoids content in mulberry and their scavenging effects on super- 
oxide radicals. Food Chem., 1999; 64: 555-559.

36. Valentovic P, Luxova M, Kolarovic L, Gasparikova O. Effect of osmotic stress on compatible solutes content, membrane stability and water relations in two maize cultivars. Plant Soil Environ, 2006; 52: 186-191.

37. Velikova V, Yordanov I, Edreva A. Oxidative stress and some antioxidant systems in acid rain-treated bean plants. Plant Sci, 2000; 151(1): 59-66. doi:10.1016/S0168-9452(99)00197-1

38. Lowry $\mathrm{OH}$, Rosebrough NJ, Farr AL, Randall RJ. Protein Measurement with the Folin Phenol Reagent. The Journal of Biological Chemistry, 1951; 193(1): 265-275.

39. Beauchamp $\mathrm{C}$ and Fridovich I. Superoxide dismutase: improved assays and an assay applicable to acrylamide gels. Anal Biochem., 1971; 44(1): 276-287.

40. Aebi H (1984) Catalase in vitro. Meth Enzymol 105:121-126.

41. Nakano Y, Asada K. Hydrogen peroxide is scavenged by ascorbate-specific peroxidase in spinach chloroplasts. Plant Cell Physiol, 1981; 22(5): 867-880.

42. Putter J. Peroxidase. In: Methods of enzymatic assays. (Ed.H.U. Bergymer), Verlag Chemie, Weinhan, 1974; 685-690.

43. Drazkiewicz M, Skorzynska-Polit E, Krupa Z. Response of ascorbate-glutathione cycle to excess copper in Arabidopsis thaliana (L.). Plant Sci, 2003; 164(2): 195-202

44. Hissin PJ and Hiff R. A fluorometric method for determination of oxidized and reduced glutathione in tissues. Anal Biochem, 1976; 74(1): 214-226.

45. Jiang $M$ and Zhang J. Effect of abscissic acid on active oxygen species, antioxidative defense system and oxidative damage in leaves of maize seedlings. Plant Cell Physiol, 2001; 42(11): 12651273.

46. Liu CW, Sung Y, Chen BC, Lai HY. Effects of nitrogen fertilizers on the growth and nitrate content of Lettuce (Lactuca sativa L.). Int. J. Environ. Res. Public Health. 2014; 11: 4427-4440.

47. Guha A, Sengupta D, Reddy AR. Polyphasic chlorophyll a fluorescence kinetics and leaf protein analyses to track dynamics of photosynthetic performance in mulberry during progressive drought. J. Photochem. Photobiol., 2013; 119: 71-83.

48. Kumar A and Prasad MNV. Lead-induced toxicity and interference in chlorophyll fluorescence in Talinum triangulare grown hydroponically. Photosynthetica, 2015; 53 (1): 66-71.

49. Boguszewska D, Zagdanska B. ROS as signaling molecules and enzymes of plant response to unfavorable environmental conditions, Oxidative Stress - Molecular Mechanisms and Biological Effects, Dr. Volodymyr Lushchak (Ed.), Rijeka, Croatia: In Tech, 2012 341-362. DOI: 10.5772/33589

50. Bhattacharjee S. Reactive oxygen species and oxidative burst: roles in stress, senescence and signal transduction in plants. Curr Sci, 2005; 89(7): 1113-1121.

51. Posmyk MM, Kontek R, Janas KM. Antioxidant enzymes activity and phenolic compounds content in red cabbage seedlings exposed to copper stress. Ecotoxicol Environ Saf, 2009; 72(2): 596602

52. Shemet SA, Fedenko VS. Accumulation of phenolic compounds in maize seedlings under toxic $\mathrm{Cd}$ influence. Physiol Biochem Cultiv Plants, 2005; 37: 505-512.

53. Sakihama Y, Cohen MF, Grace SC, Yamasaki H. Plant phenolic antioxidant and pro-oxidant activities: phenolics induced oxidative damage mediated by metals in plants. Toxicology, 2002; 177(1): 67-80.

54. Kumar A, Prasad MNV, Achary VMM, Panda BB. Elucidation of lead-induced oxidative stress in Talinum triangulare roots by analysis of antioxidant responses and DNA damage at cellular level. Environ Sci Pollut Res, 2013; 20(7): 4551-4561.

55. Kabata-Pendias A. Trace elements in soils and plants. $4^{\text {th }}$ edn. CRC Press. Boca Rato. London. Pp, 2010; 407-505

56. Kopittke PM, Asher CJ, Blamey FPC, Menzies NW. Toxic effects of $\mathrm{Pb}^{2+}$ on the growth and mineral nutrition of signal grass (Brachiar- ia decumbens) and Rhodes grass (Chloris gayana). Plant Soil, 2007; 300(1-2): 127-136.

57. Qiao X, Shi G, Jia R, Chen L, Tian X, Xu J. Physiological and biochemical responses induced by lead stress in Spirodela polyrhiza. Plant Growth Regul., 2012; 67: 217-225.

58. Sharma P, Dubey RS. Lead Toxicity in Plants. Brazilian J Plant Physiol, 2005; 17: 35-52. doi:10.1590/S1677-04202005000100004

59. Aravind P, Prasad MNV. Zinc alleviates cadmium-induced oxidative stress in Ceratophyllum demersum L.: a free floating freshwater macrophyte. Plant Physiol Biochem , 2003; 41(4): 391-397.

60. Meitei M, Kumar A, Prasad M, Malec P, Waloszek A, Maleva G, Strzalka K. Photosynthetic pigments and pigment-protein complexes of aquatic plants under heavy metal stress. Photosynthetic pigments: chemical structure, biological function and ecology. Russian Academy of Sciences, St. Petersburg, Nauka, Russia, 2014; 314-329.

61. Parys E, Wasilewska W, Siedlecka M, Zienkiewicz M, Drożak A, Romanowska E. Metabolic responses to lead of metallicolous and nonmetallicolous populations of Armeria maritima. Arch. Environ. Contam. Toxicol. 2014; 67: 565-577.

62. Yang L, Fan T, Guan L, Ren Y, Han Y, Liu Q, et al. CMDH4 encodes a protein that is required for lead tolerance in Arabidopsis. Plant Soil, 2016; 412: 317-330.

63. Chen Q, Zhang X, Liu Y, Wei J, Shen W, Shen Z, Cui J. Hemin-mediated alleviation of zinc, lead and chromium toxicity is associated with elevated photosynthesis, antioxidative capacity; suppressed metal uptake and oxidative stress in rice seedlings. Plant Growth Regul., 2016; 81: 253-264.

64. Nautiyal N, Sinha P. Lead induced antioxidant defense system in pigeon pea and its impact on yield and quality of seeds. Acta Physiol. Planta, 2012; 34: 977-983.

65. Wang $\mathrm{P}$, Zhang $\mathrm{S}$, Wang $\mathrm{C}$, Lu J. Effects of $\mathrm{Pb}$ on the oxidative stress and antioxidant response in a $\mathrm{Pb}$ bioaccumulator plant Vallisneria natans. Ecotoxicol. Environ. Saf., 2012; 78: 28-34.

66. Asada K. Ascorbate peroxidase - a hydrogen peroxide scavenging enzyme in plants. Physiol Plant, 1992; 85(2): 235-241.

67. Mishra S, Srivastava S, Tripathi RD, Kumar R, Seth CS, Gupta DK. Lead detoxification by coontail (Ceratophyllum demersum L.) involves induction of phytochelatins and antioxidant system in response to its accumulation. Chemosphere, 2006; 65(6): 10271039.

68. Wang C, Gu X, Wang X, Guo H, Geng J, Yu H, Sun J. Stress response and potential biomarkers in spinach (Spinacia oleracea L.) seedlings exposed to soil lead. Ecotoxicol Environ Saf, 2011; 74(1): 41-47.

69. Li Y, Zhou C, Huang M, Luo J, Hou X, Wu P, Ma X. Lead tolerance mechanism in Conyza canadensis: subcellular distribution, ultrastructure, antioxidative defense system, and phytochelatins. J. Plant Res., 2016; 129: 251-262.

70. Anjum NA, Ahmad I, Mohmood I, Pacheco M, Duarte AC, Pereira E, Umar S, Ahmad A, Khan NA, Iqbal M, Prasad MNV. Modulation of glutathione and its related enzymes in plants' responses to toxic metals and metalloids - a review. Environ Exp Bot, 2012; 75: 307324.

71. Strubińska J, Hanaka A. Adventitious root system reduces lead uptake and oxidative stress in sunflower seedlings. Biol. Plant, 2011; 55: 771.

72. Ali B, Mwamba TM, Gill AR, Yang C, Ali S, Daud MK, Wu Y, Zhou W. Improvement of element uptake and antioxidative defense in Brassica napus under lead stress by application of hydrogen sulfide. Plant Growth Regul, 2014; 74: 261-273. DOI 10.1007/ s10725-014-9917-9.

73. Hattab S, Hattab S, Flores-Casseres ML, Boussetta H, Doumas $\mathrm{P}$, Hernandez LE, Banni M. Characterisation of lead-induced stress molecular biomarkers in Medicago sativa plants. Environ. Exp. Bot., 2016; 123: 1-12. 